\title{
STEROID CONCENTRATIONS IN NORMAL FOLLICULAR FLUID AND OVARIAN CYST FLUID FROM COWS
}

\author{
R. V. SHORT \\ A.R.C. Unit of Reproductive Physiology and Biochemistry, \\ Department of Veterinary Clinical Studies, University of Cambridge
}

(Received 25th October 1961)

Summary. 1. The following steroids were estimated in five samples of normal bovine follicular fluid, and in twenty-four samples of cyst fluid from cows with cystic ovaries: progesterone, 17 $\alpha$-hydroxyprogesterone, androstenedione, oestrone and oestradiol-17 $\beta$. 20 $\beta$-Hydroxypregn-4en-3-one was also found in two samples of cyst fluid. No testosterone could be detected in any of the samples assayed.

2. Oestradiol-17 $\beta$ was the major steroid present in all five samples of follicular fluid. The concentration of oestradiol-17 $\beta$ was significantly lower $(P<0.01)$ in the cyst fluid.

3. Many of the cyst fluid samples contained large amounts of progesterone, but little or no detectable $17 \alpha$-hydroxyprogesterone, androstenedione, oestrone or oestradiol-17 $\beta$. Histological examination of the cyst wall in a number of these cases showed atretic or luteinization changes. In one case where luteinization had occurred, 20 $\beta$-hydroxypregn-4-en3-one was also present in the cyst fluid.

4. There was no obvious correlation between the behavioural characteristics of the 'cystic cows' and the nature or amount of the steroids present in the cyst fluid. Thus the steroid concentrations in nine 'cystic cows' with normal oestrous cycles did not differ significantly $(P>0.05)$ from the concentrations in seven nymphomaniac cows.

5. The absolute concentrations and relative amounts of the various steroids differed greatly, both between animals and within the same animal. It is therefore concluded that the cyst itself is not the primary defect in cystic ovarian disease. Both histologically and endocrinologically the cyst appears to be a degenerative structure. In the normal follicle, follicular growth and endocrine activity seem to accompany one another; in the cyst, on the other hand, follicular growth continues whilst endocrine activity is waning.

\section{INTRODUCTION}

Cystic ovaries have long been recognized as a common cause of infertility in cattle, and the relevant literature has been reviewed by Garm (1949a), Roberts (1956) and Dawson (1957). In spite of the numerous theories that have been 
put forward, the aetiology of the condition is still obscure and little is known of the associated endocrine changes.

Assay of the steroids present in follicular fluid is a convenient way of gaining information about the endocrine activity of the ovary, especially in species such as the cow and the mare in which follicular fluid can be aspirated via the vagina of the conscious animal. Investigations in the mare have shown that

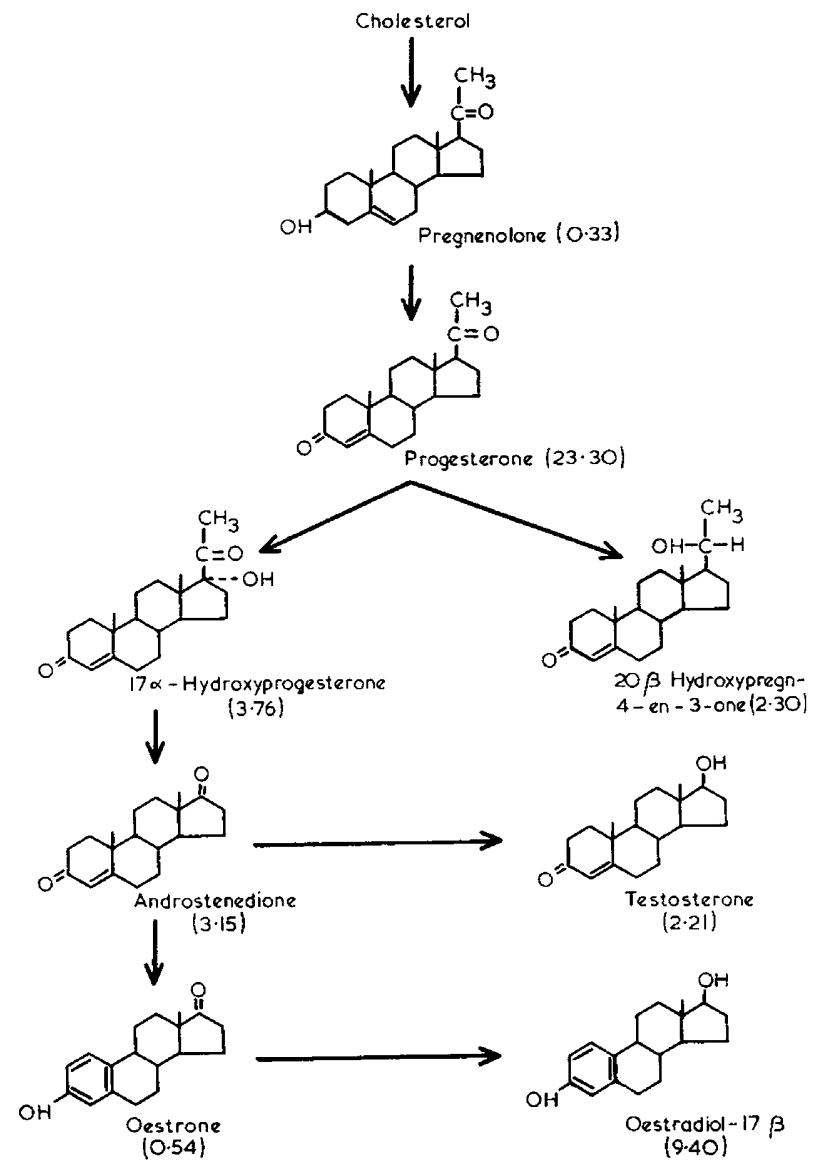

TEXT-FIG. 1. Steroids isolated from a pool of $425 \mathrm{ml}$ bovine follicular fluid, and their relationship to one another. (Concentrations expressed as $\mu \mathrm{g}$ steroid/100 ml fluid.)

most of the steroid intermediates in the conversion of cholesterol to oestradiol$17 \beta$ can be found in the follicular fluid; oestradiol- $17 \beta$ is usually the major steroid present, and the ratios of the various steroids to one another seem to be remarkably constant (Short, 1960a; 1961). However, a striking difference was observed between the steroids present in follicular fluid and those present in luteal tissue. This led to the development of a 'two-cell type' theory of steroid formation in the ovary. It was postulated that one type, probably the theca interna cell, had the ability to convert progesterone into oestrogens; the 
other type, probably the luteinized granulosa cell, had a diminished 17hydroxylating ability and was unable to cleave the $\mathrm{C}_{21}$ side chain to make $\mathrm{C}_{18}$ and $\mathrm{C}_{19}$ steroids. However, it did have an active 20-reductase enzyme system present, which was absent from the theca interna cell (Short, 1962b).

Isolation studies carried out on a large pool of bovine follicular and cyst fluid obtained from several hundred ovaries have likewise revealed the presence of most of the steroid intermediates in the conversion of cholesterol to oestradiol$17 \beta$ (Short, 1962a). The various pathways concerned are depicted in Text-fig. 1 ; the figures in brackets represent the concentrations of steroids found in the pooled sample. This initial isolation study provided the basis for the present investigation, the purpose of which was to measure the levels of these steroids in the follicular fluid of normal cows in oestrus, and to compare them with the levels found in the fluid obtained from ovarian cysts.

\section{MATERIALS AND METHODS}

Follicular fluid and cyst fluid were obtained from cows during life by puncturing the ovary with a needle introduced into the peritoneal cavity via the dorsal fornix of the vagina, in the manner described previously (Short, 1961). In addition, a number of samples of cyst fluid were obtained from slaughtered animals; in some of these cases, the ovaries were saved for histological examination. Histological sections were also prepared from normal ovaries collected from the slaughterhouse to show the luteinization changes that follow ovulation.

Once the fluid had been collected, it was placed in a refrigerator at $-15^{\circ} \mathrm{C}$ as quickly as possible, and kept frozen until it could be assayed. The assay procedure was essentially the same as that described for equine follicular fluid (Short, 1961), with the following minor modifications.

\section{Oestriol fraction}

Initially this fraction was examined as a routine; however, no phenolic steroids were ever detected. Since no phenolic steroids were found in the oestriol fraction during the isolation studies already referred to (Short, 1962a), assay of this fraction was eventually discontinued.

\section{Oestradiol +oestrone fraction}

At the beginning of the study, this fraction was chromatographed in the hexane : benzene/formamide system, as described previously (Short, 1961). This system was used because it gives a reasonable separation of oestradiol-17 $\alpha$ from oestradiol-17 $\beta$. Oestradiol-17 $\alpha$ is known to be one of the principal urinary oestrogens in the cow (Klyne \& Wright, 1956), and it has been suggested that it might also be present in the fluid obtained from cystic ovaries (Velle, 1959). However, no oestradiol-17 $\propto$ was detected in any of the samples assayed, and none was found in the initial isolation studies (Short, 1962a). In view of these negative results, the hexane: benzene/formamide chromatographic system was abandoned in favour of a modified Bush system of light petroleum : toluene (1:1)/80\% methanol. Although this failed to separate the two epimeric oestradiols, it was found to be much more convenient for routine use. 
Non-phenolic fraction

The chromatographic system used in this study failed to separate testosterone from 17 $\alpha$-hydroxyprogesterone. Since relatively large amounts of testosterone were isolated from bovine follicular fluid (Short, 1962a; see Text-fig. 1), in most cases the 17 $\alpha$-hydroxyprogesterone eluates were pooled and subsequently treated with acetic anhydride and pyridine. On re-chromatography, any testosterone acetate that might have been formed would be readily separated from the unacetylated $17 \propto-$ hydroxyprogesterone. However, none was ever detected in any of the samples that were assayed.

No attempt was made to measure pregnenolone in any of the samples, as the amounts present would probably be too low to detect (see Text-fig. 1). Similarly, 20 $\alpha$-hydroxypregn-4-en-3-one, epitestosterone and 19-norandrostenedione were not measured, as they are apparently absent from bovine follicular fluid (Short, 1962a). 20 $\beta$-Hydroxypregn-4-en-3-one was partially separated from androstenedione in the chromatographic system used, and it was only detected in two instances.

\section{CASE HISTORIES OF NORMAL COWS}

Animals 1 to 5 were in normal oestrus at the time of sampling, and the follicular fluid was collected during life via the vagina. No harmful effects were noted as a result of this procedure, and there was no impairment of subsequent fertility. This surgical rupture of the follicle did not affect the length of the ensuing oestrous cycle, so presumably it did not interfere with the normal development of the corpus luteum.

In view of the relatively small volumes of fluid that were obtained from Animals 2, 3 and 4, these samples were pooled prior to assay.

Animals 6 and 7 were no longer in oestrus at the time of collecting the follicular fluid. In both cases, a cyclical corpus luteum had been squeezed out of the ovary, followed $1 \mathrm{hr}$ later by an intravenous injection of 1500 i.u. pregnant mares' serum. They both came into oestrus 3 days later, when they were inseminated. Animal 6 was slaughtered $48 \mathrm{hr}$ later, when a recently formed corpus luteum was found in one of the ovaries, and a two-celled egg was recovered from the Fallopian tube. Follicular fluid was aspirated from numerous large follicles in both ovaries. Animal 7 was slaughtered $24 \mathrm{hr}$ after insemination, when a recent ovulation point was visible on one of the ovaries. Follicular fluid was aspirated from one or two large follicles.

These animals were included with the other five normal cows for the purpose of this investigation, and Table 2 shows that the steroid concentrations in the follicular fluid of all these animals were similar.

\section{CASE HISTORIES AND BEHAVIOURAL GHARACTERISTICS OF 'CYSTIC COWS'}

A high degree of homosexual behaviour is normally seen between cows that are in oestrus and other animals in the herd; the oestrous animal will ride other animals, or attempt to do so, and will stand to be ridden by them. In view of this fact, great care has to be taken before one can with justification say that a 'cystic cow' is showing signs of either nymphomania or virilism. At the time of 
collecting the cyst fluid from the cows used in this study, a detailed case history was therefore obtained, particular attention being paid to the behavioural characteristics and bodily configuration of each animal. Table 1 is a copy of the questionnaire that was used for this purpose.

The case histories of all the 'cystic cows' (Nos. 8 to 22) are given in an Appendix. An animal was classed as 'nymphomaniac' if it was both riding other cows, and being ridden by them, more frequently than once every 3 weeks. An animal was classed as 'virilized' if it frequently rode other cows but was not ridden by them, and if in addition it showed some signs of development of male secondary sexual characteristics, as outlined in Table 1. However, no

\section{TABLE 1}

CYSTIG OVARY INVESTIGATION QUESTIONNAIRE

Name of cow and ear No.

Name of owner.

No. of calves.

Yield (lb) last lactation
Breed

Address

Last calved

How long has the animal been cystic?

HISTORY OF CONDITION

Has the animal had cysts in a previous lactation?

Did the dam of this animal suffer from cysts?

Has the animal shown: $\quad$ regular oestrus? permanent oestrus? frequent oestrus? infrequent oestrus?

Does it ride other animals? anoestrus?

Is it ridden by other animals?

Does it have a bull-like voice?

Does it paw the ground?

Does it frequently raise its upper lip?

Is the tail-head raised?

APPEARANCE

Is there curly hair on the poll?

Are there any coarse hairs on the vulval labiae?

Are the sacro-sciatic ligaments relaxed?

Is the clitoris enlarged?

Is the brisket pronounced?

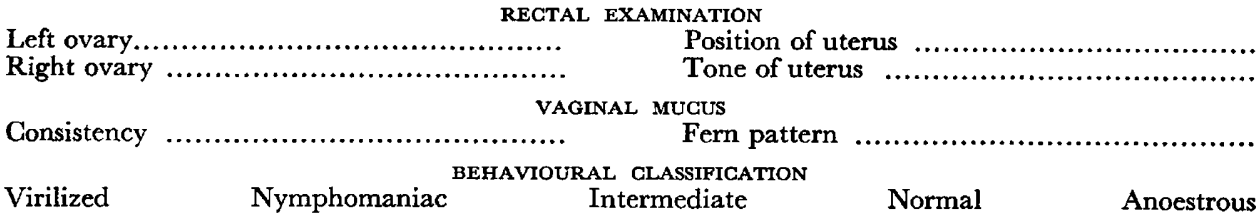

such 'virilized' animals were encountered in this study. An 'intermediate' group was recognized, in which animals might show some signs of 'nymphomania' and 'virilism' simultaneously. Some cows with cysts exhibited a 'normal' behavioural pattern, with oestrus recurring at regular intervals once every 3 weeks; others had been in a state of 'anoestrus' for relatively long periods of time.

Diagnosis of cystic ovaries

A cow was considered to have cystic ovaries if there was a follicle of greater diameter than about $2 \mathrm{~cm}$ present in either ovary. The volume of fluid contained by a sphere of $1.5 \mathrm{~cm}$ diameter would be $1.8 \mathrm{ml}$; a $2 \mathrm{~cm}$ sphere would contain $4.2 \mathrm{ml}$. 
STEROID CONCENTRATIONS IN THE FOLLICULAR FLUID OF NORMAL COWS IN OESTRUS, AND IN THE FOLLICULAR FLUID OF COWS THAT HAD BEEN TREATED WITH PREGNANT MARES' SERUM GONADOTROPHIN

Table 2 shows that five samples of normal follicular fluid were assayed from Animals 1 to 7 ; in every case oestradiol- $17 \beta$ was the major steroid present. Oestrone was also present, although in much smaller amounts; it is of interest that the mean ratio of oestradiol-17 $\beta$ : oestrone of approximately $10: 1$ is very similar to the ratio found in equine follicular fluid (Short, 1961).

On comparing the steroid concentrations in Table 2 with those found in the large pooled sample of bovine follicular fluid (Short, 1962a; as summarized in Text-fig. 1), it will be seen that, with the exception of progesterone, all the steroid concentrations found at oestrus were at least four times higher than those in the pooled sample. A similar phenomenon was noted in the case of equine follicular fluid, where the concentrations of steroids found at oestrus

TABLE 2

STEROID CONGENTRATIONS IN THE FOLLICULAR FLUID OF NORMAL COWS IN OESTRUS AND COWS TREATED WITH PREGNANT MARES' SERUM GONADOTROPHIN

\begin{tabular}{|c|c|c|c|c|c|c|c|}
\hline $\begin{array}{c}\text { Animal } \\
\mathcal{N} o .\end{array}$ & Breed & $\begin{array}{c}\text { Vol. of } \\
\text { fluid }(\mathrm{ml})\end{array}$ & Progesterone & $\begin{array}{c}17 \alpha-H y d r o x y- \\
\text { progesterone }\end{array}$ & $\begin{array}{l}\text { Androstene- } \\
\text { dione }\end{array}$ & Oestrone & $\begin{array}{c}\text { Oestradiol } \\
17 \beta\end{array}$ \\
\hline $\begin{array}{l}1 \\
2\end{array}$ & $\begin{array}{l}\text { Ayrshire } \\
\text { Shorthorn }\end{array}$ & $\begin{array}{l}2 \cdot 7 \\
1 \cdot 47\end{array}$ & $24 \cdot 0$ & $33 \cdot 4$ & $24 \cdot 0$ & $5 \cdot 6$ & $83 \cdot 6$ \\
\hline 3 & Shorthorn & 1.7 & $16 \cdot 6$ & $16 \cdot 6$ & $2 \cdot 9$ & $3 \cdot 9$ & $47 \cdot 0$ \\
\hline $\begin{array}{l}4 \\
5\end{array}$ & $\begin{array}{l}\text { Guernsey } \\
\text { Ayrshire }\end{array}$ & $2 \cdot 8$ & $5 \cdot 4$ & $16 \cdot 0$ & $5 \cdot 4$ & $12 \cdot 5$ & $75 \cdot 0$ \\
\hline 6 & Red poll & $9 \cdot 5$ & $39 \cdot 0$ & 27.4 & $24 \cdot 2$ & 3.2 & $84 \cdot 1$ \\
\hline 7 & Hereford & $3 \cdot 3$ & $3 \cdot 4$ & $10 \cdot 6$ & $<2 \cdot 0$ & $1 \cdot 5$ & $21 \cdot 2$ \\
\hline
\end{tabular}

Results expressed as $\mu \mathrm{g}$ steroid/ $100 \mathrm{ml}$ fluid.

were twice as high as those found in a pooled sample of fluid (Short, 1960a; 1961). The explanation seems to be that the larger follicles contain the higher steroid concentrations. Thus, in large pooled samples collected from animals at all stages of the cycle, much of the fluid will inevitably come from the smaller follicles with low steroid concentrations. In animals in oestrus, on the other hand, follicular development is at its maximum and the steroid concentrations are consequently higher. The high progesterone concentrations found in pooled samples may be due to the inclusion of material from follicles that are beginning to luteinize, or become atretic.

\section{STEROID CONGENTRATIONS IN THE FLUID FROM COWS WITH GYSTIC OVARIES}

Table 3 shows the steroid concentrations in twenty-four samples of cyst fluid that were assayed from Animals 8 to 22. The case histories of these animals are given in the Appendix. This table certainly seems to emphasize the endocrine heterogeneity of cystic ovaries. Not only are different steroid patterns seen in the same animal sampled on numerous different occasions (e.g. Animals 


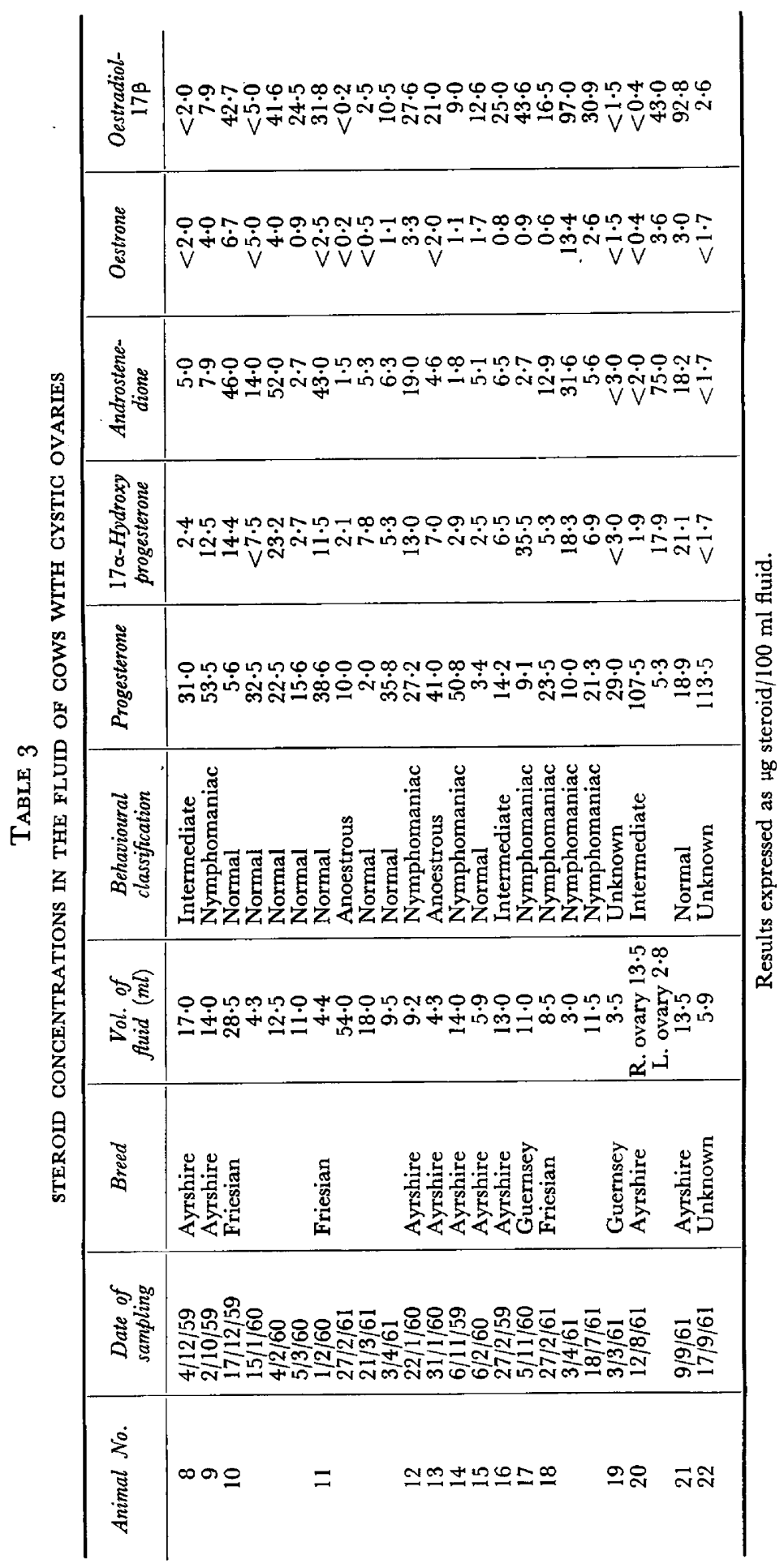


10,11 and 18), but there may also be pronounced differences between cysts present at any given time in one animal (e.g. Animal 20).

If the concentrations of the various steroids found in the cyst fluid are compared with the values for normal follicular fluid as has been done in Text-fig. 2, it will be seen that the cysts contain significantly less oestradiol-17 $\beta$ $(P<0.01)$ and $17 \alpha$-hydroxyprogesterone $(P<0.05)$ than the normal follicles. However, if the steroid concentrations in the seven nymphomaniacs listed in Table 3 are compared with the normals, there are no significant differences $(P>0.05)$. Similarly, the nine cystic animals showing a normal behavioural pattern did not differ significantly from either the nymphomaniacs or the normals $(P>0.05)$.

As follicular fluid is probably only an accumulation of ovarian interstitial

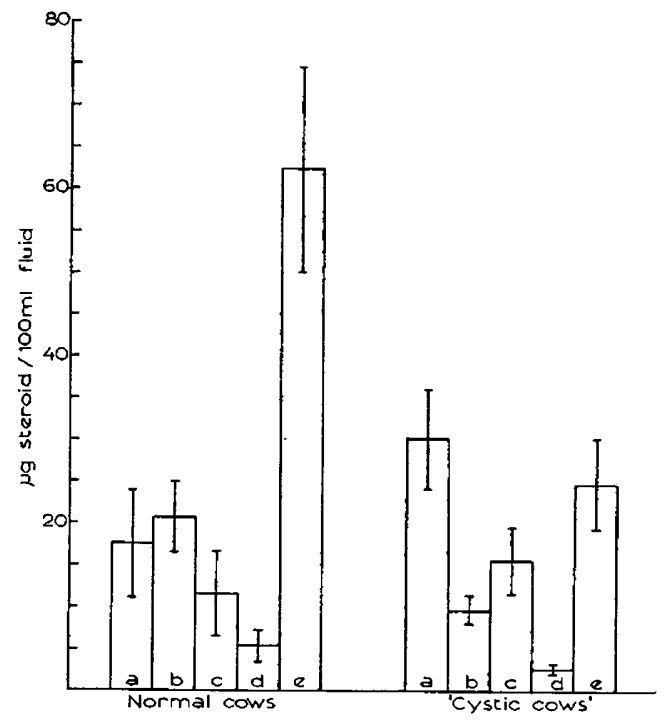

TEXT-FIG. 2. Mean concentrations of steroids in normal and cystic follicles ( $\mu \mathrm{g} / 100$ $\mathrm{ml} \pm$ s.e. $)$.

$\mathrm{a}=$ Progesterone

c $=$ Androstenedione

$\mathrm{e}=$ Oestradiol-17 $\beta$

b $=17 \alpha-H y d r o x y p r o g e s t e r o n e$

$\mathrm{d}=$ Oestrone

fluid, one might expect the steroids it contains to be in some sort of equilibrium with those present in the steroid-producing cells of the follicle, and in the blood capillaries that surround it. If this is the case, then follicular steroid concentrations might provide a more meaningful estimate of ovarian activity than the total amount of hormone present in the fluid. In the normal ovary, the factors responsible for follicular enlargement seem to go hand-in-hand with those responsible for increased steroidogenesis, hence the higher steroid concentrations in the larger follicles, referred to previously. In the cystic ovary, on the other hand, this relationship no longer holds, and the volume of the cyst gives no indication of its steroid content.

In spite of these considerations it seemed important to recalculate the data in Tables 2 and 3 in terms of the total amounts of steroids present in the follicular 
and cyst fluid. This has been done in Text-fig. 3 , and it will be seen that the values for the individual steroids do not differ between the two groups $(P$ $>0.05$ ), although the cystic animals tended to have more progesterone and less oestradiol-17 $\beta$ than the normal controls. When the nymphomaniac group was compared with the cystic animals showing a normal behavioural pattern, there were likewise no significant differences between the amounts of the individual steroids present $(P>0.05)$; neither were there any significant differences between the cystic animals with a normal behaviour and the normal controls. However, the amount of progesterone in the nymphomaniacs was significantly greater than that found in the normals $(P<0.05)$.

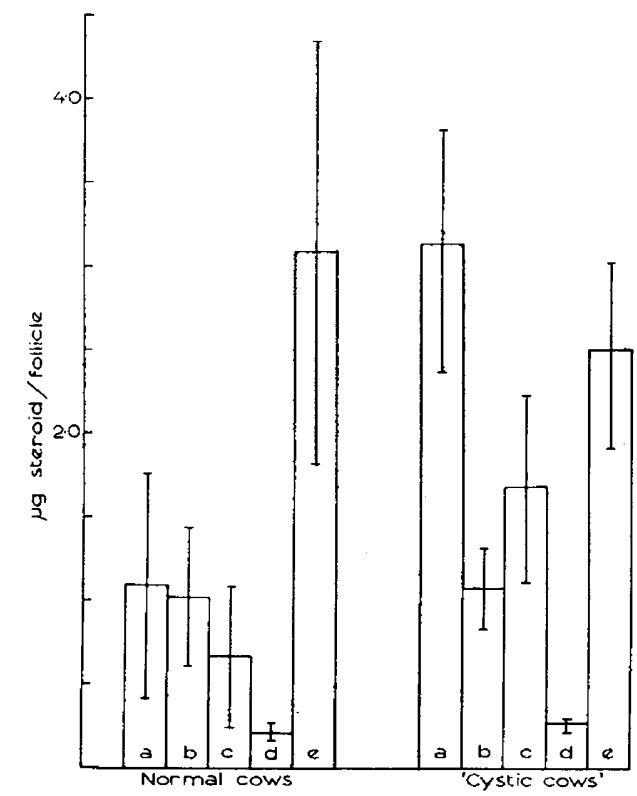

TExT-Fig. 3. Mean amounts of steroids in normal and cystic follicles ( $\mu \mathrm{g} \pm$ s.E.).

$\mathbf{a}=$ Progesterone

$\mathrm{b}=17 \alpha-\mathrm{Hydroxyprogesterone}$

c $=$ Androstenedione

$\mathrm{d}=$ Oestrone

e $=$ Oestradiol-17 $\beta$

Text-fig. 3 is also of interest in that it indicates the actual amounts of the various steroids that have to be measured. The assay procedure used is capable of estimating as little as 0.2 to $0.3 \mu \mathrm{g}$ of progesterone, $17 \alpha$-hydroxyprogesterone and androstenedione, and 0.05 to $0.1 \mu \mathrm{g}$ of oestrone and oestradiol-17 $\beta$, with reasonable accuracy. It will be seen that most of the values lie well above these limits of sensitivity.

Comparisons between groups in such a heterogeneous collection of material may fail to bring to light interesting changes in the steroid ratios between individuals. For example, there appear to be a number of animals in whose cyst fluid there is no detectable oestradiol-17 $\beta$ or oestrone (Animals 8, 10, 11, 19 and 20); in each instance, progesterone is the major steroid present. These 
animals therefore differ markedly from the normals (see Text-fig. 2), both in the absolute amounts of steroids present, and in their relative ratios to one another.

\section{HISTOLOGY OF THE GYST IN RELATION TO ITS HORMONE CONTENT}

As was mentioned in the Introduction, the theory has been advanced that there may be two biochemically and histologically distinct cell types in the ovary - the theca interna cell, which can convert progesterone through to oestrogens, and the luteal cell, derived from the granulosa cell, which cannot 17-hydroxylate progesterone to any appreciable extent, and therefore cannot make oestrogens. However, this luteal cell can synthesize the 20-hydroxy derivative of progesterone, which the theca interna cell is unable to do (Short, 1962b).

In view of this theory, it was obviously of considerable interest to compare the histological picture of the cyst with its hormone content. Unfortunately this was only possible in the case of Cows 8 (Pl. 2, Fig. 4), 14 (Pl. 2, Fig. 5), 19 (PI. 2, Fig. 6) and 22 (Pl. 2, Fig. 7).

It is generally considered that the corpus luteum in the cow is derived from the granulosa cells (Hammond, 1927), but since there are very few published illustrations of the luteinization process in the bovine ovary, these changes have been illustrated in Pl. 1, Figs. 1 to 3, for comparative purposes.

The cyst fluid of Cows 8, 14 and 19 contained mainly progesterone, although Animal 14 also had a small amount of oestradiol-17 $\beta$ present (see Table 3 ). One might, therefore, have expected to find extensive luteinization of the granulosa cells in these cysts, and few theca interna cells. Examination of Pl. 2, Figs. 4, 5 and 6 shows that this was definitely not the case. In each instance, the granulosa cells were few and far between, and they did not show the luteinization changes depicted in PI. 1, Figs. 2 and 3. The theca interna cells were difficult to distinguish as such in Animals 8 and 19, but in Cow 14 (Pl. 2, Fig. 5) the theca interna cells appeared much larger than in the normal follicle (Pl. 1, Fig. 1); in addition, they had an intensely vacuolated cytoplasm.

These histological findings indicate that the cysts in question were 'follicular cysts', in which progressive atresia and degeneration of the granulosa and theca interna were taking place; this is the characteristic histological picture seen in bovine cystic ovaries (Yamauchi \& Inui, 1954; Nushag \& Illner, 1958). The fact that high progesterone levels were found in the cyst fluid of these cows, in the absence of true luteinization changes, suggests that the atretic changes themselves are associated with an impaired ability to convert progesterone into $17 \alpha$-hydroxyprogesterone, androstenedione, oestrone and oestradiol-17 $\beta$. This would explain the prevalence of cysts containing high progesterone and low oestrogen concentrations noted in the present study. Yamauchi \& Inui (1954) and Nushag \& Illner (1958) similarly found low oestrogenic activity in the fluid from atretic cysts.

The histological picture of the cyst from Cow 22 (PI. 2, Fig. 7), and its macroscopic appearance (see Appendix) indicated that this was a true 'Iuteal cyst', formed by luteinization of the cyst wall in the absence of ovulation. Pl. 2, Fig. 7 shows that typical luteal cells were present, interspersed with stromal 


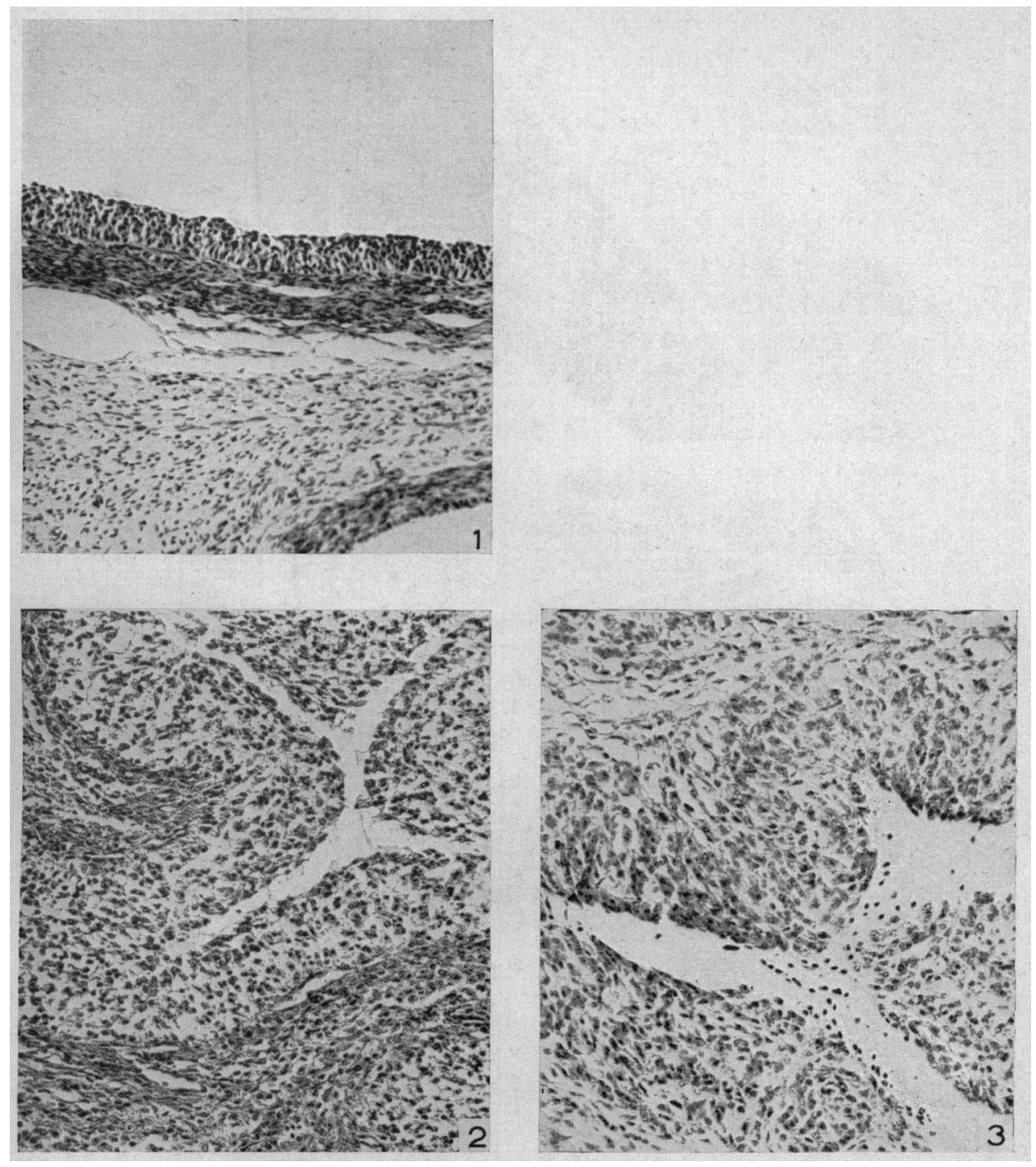

Frg. 1. Normal ovary. Lining of large follicle that contained $1.0 \mathrm{ml}$ fluid. A regressing corpus luteum was present in the same ovary, and the cervical mucus showed a positive fern pattern. This cow was probably just coming into oestrus.

Note densely packed granulosa cells with little cytoplasm and hyperchromatic nuclei. Theca interna layer is well developed. $\times 130$.

FIG. 2. Normal ovary. Early corpus luteum, probably only a few hours after ovulation. Note increased thickness of granulosa layer, indistinct cell outlines, ballooning of cytoplasm and loss of hyperchromatic nuclei. Theca interna cells are difficult to distinguish from the stromal tissue in the trabeculae. $\times 130$.

FIG. 3. Normal ovary. Early corpus luteum, slightly later stage than Fig. 2. A few lymphocytes are present in the lumen of the collapsed follicle, and luteinization changes are now well established in the granulosa cells. They have acquired even more cytoplasm. Theca interna cells no longer distinguishable as such. $\times 130$.

(Facing p. 36) 
connective tissue; a broad band of fibrous connective tissue separated these luteal cells from the cyst lumen. Progesterone was the major steroid in the cyst fluid, and there was only a trace of oestradiol-17 $\beta$ present (see Table 3). In addition to these two steroids, and not listed in Table 3, it was also possible to detect 20ß-hydroxypregn-4-en-3-one in a concentration of $20.4 \mu \mathrm{g} / 100 \mathrm{ml}$ cyst fluid. This is of considerable interest, since as already mentioned, the luteal cell seems to be capable of synthesizing one or other of these 20-hydroxyderivatives of progesterone; the bovine corpus luteum makes predominantly the 20ß-epimer (Gorski, Dominguez, Samuels \& Erb, 1958) and it is significant that this steroid was not present in any of the samples of normal follicular fluid assayed in this study. The presence of 20ß-hydroxypregn-4-en-3-one in cyst fluid may, therefore, serve to distinguish between 'luteal cysts', and 'follicular cysts' that are undergoing atresia. 20ß-Hydroxypregn-4-en-3-one was only detected in one other sample in the present study (Cow 20, right ovary, $10.0 \mathrm{\mu g} / 100 \mathrm{ml}$ ), so presumably this also came from a 'luteal cyst'.

\section{DISGUSSION}

The theories as to the causes and consequences of cystic ovaries in cattle are too numerous to be reviewed at length here, although some of them deserve comment.

\section{OESTROGEN PRODUCTION BY THE GYST}

It is a popular supposition that cows with cystic ovaries, especially those animals with raised tail-heads and relaxed sacro-sciatic ligaments, are suffering from an excessive ovarian production of oestrogens. However, there is little experimental evidence in support of this concept. Although numerous workers have attempted to measure oestrogens biologically in follicular fluid and cyst fluid from cows (Yamauchi \& Inui, 1954; Duncan, Casas, Emmerson \& Melampy, 1955; Bitman, Wrenn \& Sykes, 1958; Nushag \& Illner, 1958), it is difficult to attach much quantitative significance to their findings. The first reliable chemical assays were those carried out by Velle (1959). He was able to measure oestradiol-17 $\beta$ in nine samples of bovine cyst fluid, where he found a mean concentration of $23.9 \mu \mathrm{g} / 100 \mathrm{ml}$ (range $5 \cdot 3$ to 64.4 ). In contrast to this, he was only able to detect $6.37 \mu \mathrm{g} / 100 \mathrm{ml}$ in a pool of follicular fluid obtained from 112 normal ovaries. It can be seen that Velle's results in the cystic animals are in close agreement with those presented in Table 3, and they are significantly lower $(P<0.01)$ than the concentrations of oestradiol-17 $\beta$ in normal follicles, as given in Table 2 . The low oestradiol-17 $\beta$ concentration found by Velle in a pooled sample of normal follicular fluid agrees well with the results of a similar study carried out by Short (1962a, as summarized in Text-fig. 1). The reason why these values in pooled samples are so much lower than those found in follicular fluid collected at oestrus has already been discussed.

Regardless of whether one considers the concentrations or the total amount of oestradiol- $17 \beta$ in the cyst fluid, there is thus no evidence to suggest that the cysts themselves are producing increased amounts of oestrogens. In fact, the 
histological findings of numerous workers, as confirmed in this study, indicate that the steroid-producing cells are usually undergoing atresia, and if anything are making less oestrogen than normal. However, it is possible that the nymphomaniac animal could be producing oestrogens elsewhere in the ovary. It also seems likely that the cysts themselves may produce oestrogens for longer periods at a time, and more frequently, than the follicles in the ovary of a normal cow coming into oestrus only once every 3 weeks. The fact that cystic cows may show frequent irregular oestrus associated with the characteristic viscosity changes in the cervical mucus (Blackburn \& Castle, 1959) suggests that this is the case.

\section{'ADRENAL VIRILISM'}

This term was used by Garm (1949b) to describe a syndrome in cattle associated with cystic ovaries. He observed that some cows with cystic ovaries exhibited certain masculine behavioural and anatomical characteristics; urinary analyses in these cases revealed greatly elevated '17-ketosteroid' values, as measured by the Pincus or Zimmermann colour reactions (Meschaks, 1948). Bio-assay of urinary extracts also showed an increased androgen excretion in such cases (Garm \& Meschaks, 1949). The term 'adrenal virilism' has since been used by some authors to describe the masculinized cow with cystic ovaries (Dawson, 1958).

In view of recent discoveries, however, it has become necessary to reappraise the evidence for implicating the adrenals in this syndrome. In the first place, it is now known that bovine urine contains a number of ionone derivatives of dietary origin that give false positive colour reactions with the Pincus and Zimmermann 17-ketosteroid reagents (Holtz, 1954; Mixner, Saunders \& Johnson, 1957). In actual fact, the true 17-ketosteroid levels in bovine urine are extremely low indeed, the total ketosteroid content probably not exceeding 0.3 mg/litre (Marker, $1939 \mathrm{a}$ and b; Holtz, 1957; Klyne \& Wright, 1959). These findings therefore invalidate the conclusions of Meschaks (1948).

It is now well recognized that some of the androgenic compounds present in urine can be derived from non-androgenic precursors such as cortisol (see review by Short, 1960b); the cow may even produce androgenic metabolites from progesterone (Miller \& Turner, 1955). Whereas the bovine adrenal seems to be a very poor source of androgens (Short, 1960b), there are at least two androgens, testosterone and androstenedione, present in bovine ovaries (Short, 1962a); both of these steroids would be expected to contribute to the androgenic steroids in bovine urine.

It is thus clearly impossible to decide from urinary analyses if the adrenals are producing an excessive amount of androgen. It is, therefore, doubtful if 'adrenal virilism' really exists in cattle.

\section{ANDROGEN PRODUCTION BY THE CYST}

The present study has provided further evidence about ovarian androgen production in the cow; cystic cows do not seem to differ from the normal in this respect, even when they are apparently showing signs of masculine behaviour. In women with bilateral polycystic ovaries who are exhibiting all the 
clinical features of the Stein-Leventhal syndrome, it has recently been shown that there is a defect in the conversion of androstenedione to oestrone within the ovary; this results in an excessive accumulation of androstenedione in the cyst fluid, which may in part be responsible for the hirsutism that is sometimes seen in these patients (Short \& London, 1961). There was no evidence to suggest the presence of such a defect in any of the cystic ovaries studied here, and the two conditions are obviously completely dissimilar, both histologically and endocrinologically.

Although testosterone was never detected in any of the samples assayed in this study, the fact remains that relatively large amounts were identified in a pool of bovine follicular fluid that included material from a variety of ovarian cysts (Short, 1962a). It is, therefore, entirely possible that the occasional cow might produce large amounts of testosterone in its ovaries.

It has recently been suggested by Gawienowski, Lee \& Marion (1961) that one of the ways in which the cystic ovary differs from normal is in its ability to metabolize progesterone to androsta-1:4-diene-3:17-dione; they were able to demonstrate the in-vitro conversion of progesterone to this steroid with a $0.0142 \%$ yield in one incubation experiment. Although androsta-1 :4-diene-3: 17-dione is known to be present in bovine faeces (Miller, Turner, Fukushima \& Salamon, 1956), it was never detected in any of the ovarian samples assayed in this study.

\section{BEHAVIOURAL PATTERN OF COWS}

The results presented in Table 3 suggest that it is probably impossible to correlate the behaviour of a cystic cow with the steroids present in the cyst. The picture is undoubtedly complicated by the fact that both progesterone and testosterone (in the form of testosterone propionate) can potentiate the action of oestrogens in bringing a cow into oestrus; furthermore, progesterone in larger doses can also inhibit oestrus in an oestrogen-primed animal (Melampy, Emmerson, Rakes, Hanka \& Eness, 1957). Asdell, Alba \& Roberts (1945) and Glover (1960) have demonstrated that cows may become refractory to oestrogens, and fail to show signs of heat even though there is still plenty of oestrogen present in the body. In addition to all these factors, the behaviour of a cystic cow is also likely to be influenced by the frequency with which new, hormonally active cysts are formed in the ovaries.

There is still no adequate explanation for the fact that normal cows go out of oestrus 10 to $12 \mathrm{hr}$ before ovulation. It has been proposed by Hansell \& Trimberger (1952) that just before ovulation the follicle might start to secrete more progesterone; they were able to show that 5 to $10 \mathrm{mg}$ progesterone injected at the beginning of oestrus significantly shortened the duration of oestrus and hastened ovulation. They also speculated that a failure in the preovulatory production of progesterone might be one of the causes of ovulatory failure and cystic ovaries. The results of the present study do not lend support to this concept; cystic cows tended to have more progesterone in their cyst fluid than normal cows, and amongst the normals there was no obvious difference in progesterone concentration between those animals that were in oestrus and those that had actually ovulated. 
CAUSE OF GYSTIC OVARIES, AND TREATMENT OF THE CONDITION

The fact that the steroid patterns seen in the cyst fluid vary so greatly between and within animals suggests that the presence of cysts is a consequence rather than a cause of the condition. There is probably no inherent endocrine defect in the cyst that distinguishes it from a normal follicle, or one that is undergoing the normal process of atresia.

In the normal follicle, it appears that follicular growth and endocrine activity normally accompany one another. In the cyst, on the other hand, follicular growth continues whilst endocrine activity is apparently on the wane. Whether this is due to a failure of the ovulatory mechanisms within the ovary, or whether it is due to a derangement in pituitary gonadotrophin secretion is still open to speculation. The fact that luteinizing hormone therapy is often effective in curing the condition (Casida, McShan \& Meyer, 1944; Hancock, 1947; Yamauchi, 1955; Roberts, 1956), together with Garm's observations that the pituitaries of affected animals are significantly heavier than normal (Garm, 1949a), all point to the existence of a pituitary defect. Yamauchi, Ashida \& Inui (1954) likewise reached a similar conclusion.

Until the precise nature of the primary defect is understood more clearly, there would appear to be two rational lines of therapy; establishment of a functional corpus luteum in the ovary either by luteinizing hormone therapy or cyst rupture, or the inhibition of the pituitary by exogenously administered progestational compounds.

A point to be remembered if the former approach is adopted is that the bovine corpus luteum is thought to be formed almost exclusively from the granulosa cells (Hammond, 1927). Since these are the first cells to undergo degenerative changes in the cystic follicle, there may be insufficient granulosa cells present at the time of cyst rupture to allow a normal corpus luteum to be formed. The injection of luteinizing hormone, or manual rupture of the cyst, would, therefore, be expected to be most successful if performed as soon as possible after cyst formation.

\section{ACKNOWLEDGMENTS}

I would like to express my thanks to Dr F. L. M. Dawson, Mr L. E. A. Rowson and $\mathrm{Mr}$ P. S. Bridge for having provided me with a number of the samples used in this study. I am also grateful to $\mathrm{Dr}$ J. H. Gaddum and Mr E. J. H. Ford for allowing me to collect samples of follicular fluid from normal cows at the A.R.C. Institute of Animal Physiology, Babraham. Dr T. Mann very kindly read the manuscript and made a number of valuable suggestions; Miss Iris Levett helped carry out the steroid assays, and was of great assistance in preparing the paper for the press.

\section{REFERENCES}

Asdell, S. A., Atba, J. de \& Roberts, J. S. (1945) The levels of ovarian hormones required to induce heat and other reactions in the ovariectomized cow. F. Anim. Sci. 4, 277.

Bitman, J., Wrenn, T. R. \& Sykes, J. F. (1958) Estrogen Determination in Blood and Body Fluids of Cattle. Reproduction and Infertility IIIrd Symposium. Ed. F. X. Gassner. Pergamon Press, London. 
Blackburn, P. S. \& Castle, M. E. (1959) The use of the oestroscope and its value in detecting oestrus in dairy cattle. Brit. vet. F. 115, 399.

Casida, L. E., MCShan, W. H. \& Meyer, R. K. (1944) Effects of an unfractionated pituitary extract upon cystic ovaries and nymphomania in cows. F. Anim. Sci. 3, 273.

Dawson, F. L. M. (1957) Bovine cystic ovarian disease - a review of recent progress. Brit. vet. $\mathcal{F}$. $113,112$.

Dawson, F. L. M. (1958) Bovine cystic ovarian disease: an analysis of 48 cases. Article 2, part 1. Brit. vet. 7. 114, 96.

Duncan, G. W., Casas, I., Emmerson, M. A. \& Melampy, R. M. (1955) Estrogens in bovine blood, ovarian tissue and follicular fluid. Fed. Proc. 14, 40.

GARM, O. (1949a) A study on nymphomania, with special reference to etiology and pathogenesis. Acta endocr., Copenhagen, Suppl. 3.

GARM, O. (1949b) Investigations on cystic ovarian degeneration in the cow, with special regard to etiology and pathogenesis. Cornell Vet. 39, 39.

Garm, O. \& Meschaks, P. (1949) Investigations on the urinary androgen excretion in endocrinely normal non-pregnant cows and in cows with adrenal virilism. Nord. Vet. Med. 1, 967.

Gawienowski, A. M., LeE, S. L. \& Marion, G. B. (1961) The in vitro metabolism of progesterone-C ${ }^{14}$ to $\Delta^{1,4}$-androstadiene-3:17-dione by a cystic bovine ovary. Endocrinology, 69, 388 .

GLover, F. A. (1960) The response to ovarian hormone administration in the cow estimated from the physical properties of cervical secretions. F. Endocrin. 20, 56.

Gorski, J., Dominguez, O. V., Samuels, L. T. \& ERb, R. E. (1958) Progestins of the bovine ovary. Endocrinology, 62, 234.

Hammond, J. (1927) The physiology of reproduction in the cow, p. 78. Cambridge University Press.

HanCoCK, J. L. (1947) Clinical observations on the use of luteinizing hormone (Chorionic Gonadotrophin) in the treatment of ovarian cysts in the bovine. Vet. Rec. 59, 639.

Hansell, W. \& Trimberger, G. W. (1952) The effect of progesterone on ovulation time in dairy heifers. F. Dairy Sci. 35, 65.

Holtz, A. H. (1954) Identification of certain 'Ketosteroids' from cattle urine as ionone derivatives. Nature, Lond. 174, 316.

HoLtz, A. H. (1957) 17-Ketosteroids and pseudo-ketosteroids in the urine of cattle. Acta endocr., Copenhagen, 26, 75.

KLYNE, W. \& WRIGHT, A. A. (1956) Steroids of pregnant cow's urine. F. Endocrin. 14, xxxiii.

KLYNE, W. \& WRight, A. A. (1959) Steroids and other lipids of pregnant cows' urine. F. Endocrin. $18,32$.

MARKer, R. E. (1939a) Sterols. LVII. Ketonic steroids from cows' pregnancy urine and bulls' urine. 7. Amer. chem. Soc. 61, 944.

Marker, R. E. (1939b) Sterols. XLI. The steroidal content of steers' urine. F. Amer. chem. Soc. 61, 1287.

Melampy, R. M., Emmerson, M. A., Rakes, J. M., Hanka, L. J. \& Eness, P. G. (1957) The effect of progesterone on the estrous response of estrogen-conditioned ovariectomized cows. F. Anim. Sci. 16, 967.

Meschaks, P. (1948) Orientating investigations of neutral steroids in urine of cattle and horses. Skand. VetTidskr. 5, 278.

Miller, W. R. \& Turner, C. W. (1955) Fecal androgen, a progesterone metabolite in the bovine. Proc. Soc. exp. Biol., N.Y. 90, 142.

Miller, W. R., Turner, G. W., Fukushima, D. K. \& Salamon, I. I. (1956) The identification of $\mathrm{C}_{19}$ steroids in bovine feces. 7. biol. Chem. 220, 221.

Mixner, J. P., Saunders, H. L. \& Johnston, J. E. (1957) Study of some chromogens in cow urine. F. Dairy Sci. 40, 67.

Nushag, W. \& ILlner, F. (1958) Die Eierstockzysten des Rindes und ihre Beziehungen zur Nymphomanie. Arch. exp. VetMed. 12, 392.

Roberts, S. J. (1956) Veterinary obstetrics and genital diseases, p. 327. Stephen J. Roberts. Ithaca, New York.

Short, R. V. (1958) Progesterone in blood. I. The chemical determination of progesterone in peripheral blood. F. Endocrin. 16, 415.

Short, R. V. (1960a) Steroids present in the follicular fluid of the mare. F. Endocrin. 20, 147.

Short, R. V. (1960b) The secretion of sex hormones by the adrenal gland. Biochem. Soc. Symp. 18, 59.

SHORT, R. V. (1961) Steroid concentrations in the follicular fluid of mares at various stages of the reproductive cycle. F. Endocrin. 22, 153.

SHORT, R. V. (1962a) Steroids present in the follicular fluid of the cow. F. Endocrin. 23, 401.

SHORT, R. V. (1962b) Steroids in the follicular fluid and the corpus luteum of the mare. A 'two cell type' theory of ovarian steroid synthesis. 7. Endocrin. 24, 59. 
Short, R. V. \& London, D. R. (1961) Defective synthesis of ovarian steroids in the Stein-Leventhal syndrome. Brit. med. F. 1, 1724.

VELLE, W. (1959) Undersokelser over naturlig forekommende ostrogener hos drovtyggere og gris. Thesis, Norges veterinaerhøgskole. p. 111.

Yamauchi, M. (1955) Studies on the ovarian cyst in the cow. IV. The course of recovery from ovarian follicle cyst by the chorionic gonadotrophin therapy. Jap. 7. vet. Sci. 17, 47.

Yamauchi, M., Asmida, K. \& INUI, S. (1954) Studies on the ovarian cyst in the cow. III. Endocrinological studies on the cause of the ovarian cyst. Fap. 7. vet. Sci. 16, 65.

YamavaHr, M. \& INur, S. (1954) Studies on the ovarian cyst in the cow. II. Endocrinological and histological studies on the correlation between the ovarian cyst and the symptom. $\mathcal{J} a p . \mathcal{F}$. vet. Sci. 16, 27.

\section{Appendix}

Cow 8. This animal was 10 years old, and had had six calves. She consistently gave over 1000 gal milk per lactation. Fluid was collected at slaughter from two cysts in the right ovary; the left ovary was apparently normal, and there was no corpus luteum present. At the time of slaughter, both horns of the uterus were distended with pus. This cow had been cystic for 1 year, and had developed a markedly raised tail-head and relaxed sacro-sciatic ligaments. She actively sought out and rode any cow in oestrus, and was always having horning contests with the bull; her clitoris was slightly enlarged. Since she would occasionally stand to be ridden by other cows, she was classed as an intermediate' type. Histological examination of the cyst wall (see Pl. 2, Fig. 4) revealed a denuded granulosa layer, only 1 to 2 cells thick, and an indistinguishable theca interna layer.

Cow 9. This animal was 10 years old, had had seven calves, and gave over 1000 gal milk in the previous lactation. Fluid was collected at slaughter from three cysts in the right ovary. The left ovary contained two normal-sized follicles; there was no corpus luteum present in either ovary. This animal had been in continuous oestrus for 4 weeks, was always being ridden by other cows, and had become very excitable; she was, therefore, classed as a 'nymphomaniac'. The tail-head was slightly raised, and there was a slight enlargement of the clitoris. The cervical mucus showed a negative fern pattern.

Cow 10. This animal was 8 years old, had had five calves, and gave over 1000 gal milk in the previous lactation. She had been cystic for 2 years, in spite of repeated treatment with chorionic gonadotrophin. Oestrus occurred at 3-week intervals, and lasted about 3 days; she was therefore classed as a 'normal'. There was no elevation of the tail-head or relaxation of the sacro-sciatic ligaments, and in all other respects the animal's behaviour and appearance were essentially normal.

Cysts were punctured in both ovaries on 5 th December 1959, but by 17th December they had reappeared. They were punctured again, and the fluid was found to contain appreciable amounts of androstenedione and oestradiol-17 $\beta$. In an effort to suppress the formation of further cysts, the animal was placed on intramuscular progesterone therapy, $100 \mathrm{mg}$ daily for 8 days, starting on 17th December. A rectal examination was performed on 1st January 1960, and no cysts were present. The animal returned to oestrus within a few days, 
and the cysts once more reappeared. A second sample of cyst fluid was therefore obtained on 15th January from small cysts in both ovaries. A sample of 1 litre of peripheral blood taken at the same time and assayed by the procedure of Short (1958) failed to reveal the presence of any progesterone $(<0.2 \mu \mathrm{g} / 100 \mathrm{ml}$ plasma). This suggested that there was little functional luteal tissue present in the ovaries. Three weeks elapsed, and the animal was re-examined on 4th February; a large cyst was found in the right ovary. She was, therefore, given two intravenous injections of $25 \mathrm{mg}$ of a pituitary luteinizing hormone preparation (Armour P.L.H.) with a $3 \mathrm{hr}$ interval between injections; $3 \frac{1}{2} \mathrm{hr}$ after the second injection the cyst fluid was collected. The luteinizing hormone therapy evidently failed to induce the formation of luteal tissue, and cysts reappeared within 2 weeks. These were punctured again on 5th March.

This cow was eventually slaughtered; unfortunately the ovaries were not available for examination.

Cow 11. This animal was 10 years old when first examined, and had had seven calves; she had given over 2500 gal milk in the previous lactation. Fluid was collected from two cysts in the right ovary, and the left ovary felt normal. She had been cystic for 7 months, with recurrent oestrus lasting 1 to 2 days every 3 weeks. There were no behavioural or anatomical abnormalities, and she was therefore classed as a 'normal'. She subsequently became pregnant, and calved on 14th December 1960. She was now classed as an 'anoestrous', since she did not return to heat after calving. She was examined on 27th February 1961 and was found to have a very large cyst in the left ovary, from which $54 \mathrm{ml}$ fluid was aspirated. She subsequently came into oestrus on 11th March, and was examined on 21st March. There appeared to be a corpus luteum in the left ovary, and a large cyst was aspirated in the right ovary. She returned to oestrus on 3rd April at which time the left ovary contained no significant structures, and a cyst was present in the right ovary. This animal continued to return to oestrus, and after various forms of hormonal therapy, she eventually became pregnant.

Cow 12. This animal was 5 years old, and had last calved on 5th December 1959. She had since come into more or less continuous oestrus, always riding other animals or being ridden by them; she was therefore classed as a 'nymphomaniac'. She was last observed in oestrus the day before fluid was collected from a cyst in her right ovary. The left ovary was inactive, and no corpus luteum was palpable. The tail-head was slightly elevated and the cervical mucus showed a positive fern pattern; in all other respects the animal's appearance was normal.

Cow 13. This animal was 13 years old, and had consistently given over 1000 gal milk per lactation. She calved on 8th August 1959 and had returned to oestrus and been inseminated on 6th October, 3rd November, 23rd November and 12th December. She had subsequently become 'anoestrous', and was examined on 31st January 1960. The tail-head was raised, and the sacrosciatic ligaments were relaxed. A small cyst was present in the left ovary, and the contents were aspirated.

Cow 14. This animal was $3 \frac{1}{2}$ years old and had had one calf. The history was complicated by the fact that she had been pregnant, and the pregnancy had 
been terminated in the 3rd month by enucleation of the corpus luteum, and the intramuscular administration of $100 \mathrm{mg}$ stilboestrol. Within 2 days of the stilboestrol injection she came into oestrus, and remained in oestrus for 1 month. She was then anoestrous for 2 weeks, and returned to oestrus for 1 week; at the end of this time she was slaughtered. In view of the history she was classed as a 'nymphomaniac'. She had a raised tail-head and relaxed sacro-sciatic ligaments, and the cervical mucus showed a slight fern formation. Three cysts were present in the left ovary. Histological examination of the cyst wall (see Pl. 2, Fig. 5) revealed a thin granulosa layer, 1 to 2 cells thick, and a degenerating, vacuolated theca interna layer.

Cow 15. This animal was 13 years old, and had been cystic for 2 months; however, she was not showing any behavioural abnormalities, and was classed as a 'normal'. The cervical mucus showed no fern pattern. Cysts were present in both ovaries, and fluid was collected from a cyst in the right ovary.

Cow 16. This animal was 9 years old, and had had six calves, giving over 1000 gal milk in her previous lactation. She had been cystic for 9 months, and was having irregular oestrous cycles. The tail-head was markedly elevated, and the clitoris was somewhat enlarged. She frequently rode other cows, had a bulllike voice, and pawed the ground like a bull. However, she was also ridden by other animals on occasions, and was, therefore, classified as an 'intermediate' in behaviour. At the time of slaughter, the cervical mucus showed a very poor fern pattern: there was a cyst in each ovary, but no corpus luteum was present.

Cow 17. This animal was 11 years old, and had had eight calves. She had been cystic for about 1 year, and was showing irregular oestrous cycles. She rode any other cows on heat, and was often ridden by them; the tail-head was raised, the sacro-sciatic ligaments were relaxed, and the clitoris was slightly enlarged. She was said to have a bull-like voice, but it was decided to classify her as basically a 'nymphomaniac'. The cervical mucus showed a positive fern pattern. Fluid was obtained from cysts in both ovaries.

Cow 18. This animal was 9 years old, and was the daughter of Cow 11. She had had six calves, and gave 860 gal milk in the previous lactation. She had been cystic for 8 months, in spite of repeated treatment with chorionic gonadotrophin. Since she was frequently coming into oestrus and riding other animals in the herd, she was classed as a 'nymphomaniac'. In appearance she was essentially normal.

Fluid was collected from a cyst in each ovary on 27th February 1961, and she was put on to $17 \alpha$-hydroxyprogesterone capronate therapy (PrimulotDepot, Schering), $250 \mathrm{mg}$ twice weekly for 2 weeks, in an attempt to inhibit the development of further cysts. She did not come into oestrus during this treatment, and on examination 5 days after the last injection, no cysts could be palpated in either ovary. She soon reverted to her nymphomaniac behaviour, and on 3rd April fluid was collected from a cyst in her right ovary. She was subsequently put on a course of intramuscular progesterone therapy, $4 \times 100$ $\mathrm{mg}$ at 2-day intervals. On examination after the last injection, cysts were palpable in both ovaries; she was therefore given 750 i.u. chorionic gonadotrophin intravenously. She continued to behave like a nymphomaniac, and fluid was once more collected from cysts in both ovaries on 18th July 1961. 

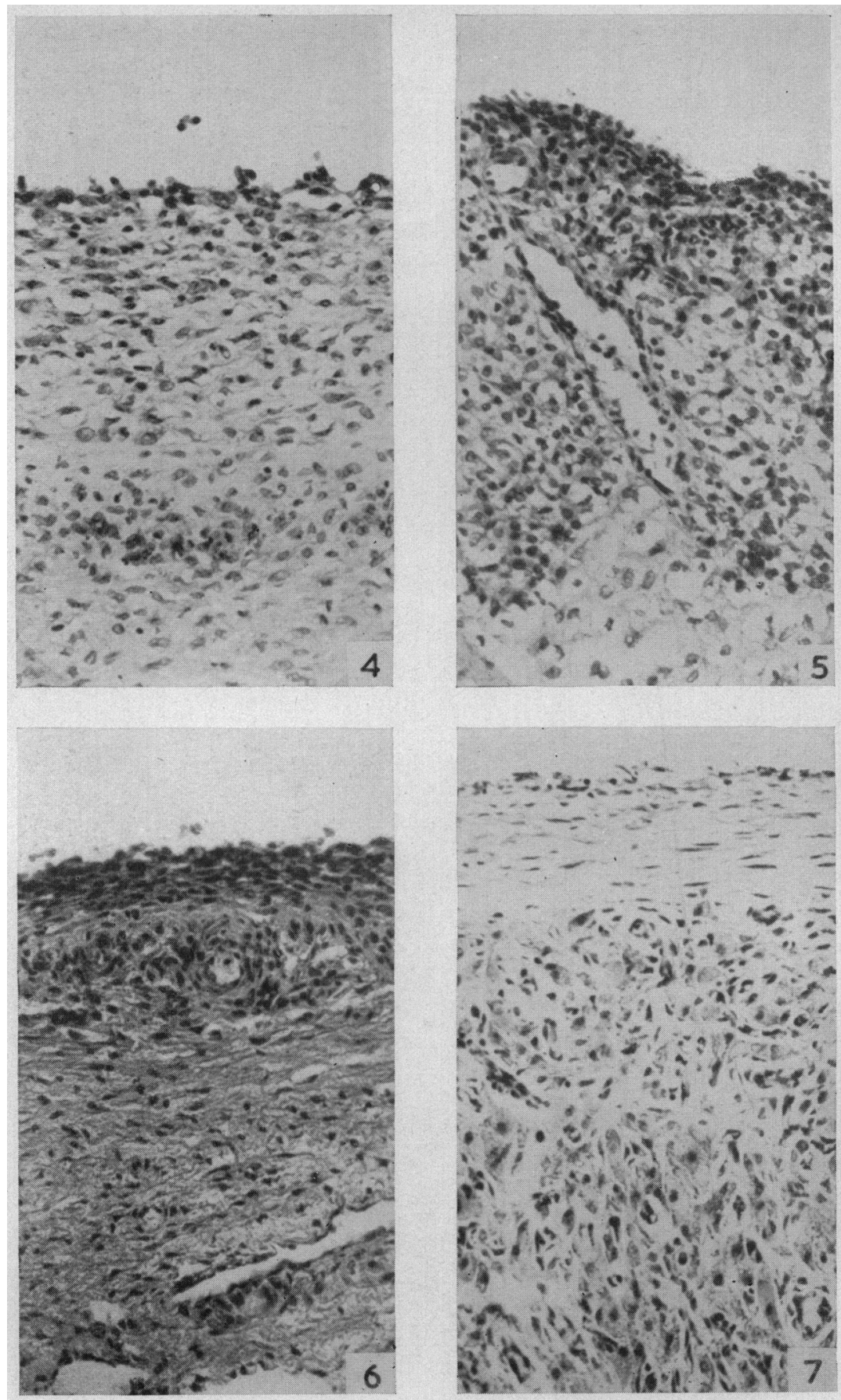

(Facing p. 45) 
Cow 19. No detailed case history was available for this animal. Her clitoris appeared normal, and her tail-head was slightly raised. Fluid was obtained from a cyst at post mortem, and histological examination of the cyst wall (see Pl. 2, Fig. 6) showed areas of necrosis and an indistinct theca interna.

Cow 20. This animal was $7 \frac{1}{2}$ years old; she had had seven calves, including two sets of twins. In her previous lactation she had given 1200 gal milk. She had been calved 4 months, and had been cystic for several weeks. Oestrus occurred infrequently, although she often rode other cows in the herd. She had a somewhat bull-like voice, and frequently pawed the ground, rubbed her head on the ground, and raised her upper lip. It was, therefore, decided to classify her as an 'intermediate' in behaviour. Her tail-head was raised, and the clitoris was slightly enlarged, but other than this her appearance was normal. Two samples of fluid were obtained, one from a cyst in the left ovary and one from a cyst in the right ovary; they were assayed separately.

Cow 21. This animal was 12 years old; she had had ten calves, including one set of twins, and gave $900 \mathrm{gal}$ milk in the previous lactation. She had had regular oestrous cycles since calving, and was therefore classified as a 'normal'. Fluid was obtained from cysts in both ovaries at the time of oestrus.

Cow 22. No case history was available for this animal. A typical 'luteal cyst' was present in one ovary. This was formed from an unovulated follicle whose wall was showing macroscopic signs of luteinization; a thin rind of luteal tissue lined the entire cyst cavity except for a small area over the surface of the ovary. Histological sections of the cyst (see Pl. 2, Fig. 7) revealed numerous luteal cells separated from the fluid-filled cavity in the centre of the cyst by a thick layer of connective tissue. There was a small follicle adjacent to the luteal cyst, but no true corpus luteum in either ovary. The cervical mucus showed a positive fern pattern.

\section{EXPLANATION OF PLATE 2}

Fig. 4. Cystic ovary. Cow 8 . Very few granulosa cells are present, and the theca interna cells are indistinguishable from the rest of the ovarian stroma. This cyst contained mainly progesterone, and no oestrogens could be detected. $\times 200$.

Fig. 5. Cystic ovary. Cow 14 . Very few granulosa cells are present. The theca interna cells appear larger than normal, and have many vacuoles in their cytoplasm. This cyst contained mainly progesterone, with a trace of oestradiol-17 $\beta . \times 200$.

FIG. 6 . Cystic ovary. Cow 19. The cyst is lined by cells that are apparently undergoing necrosis; theca interna and granulosa cells as such are difficult to distinguish. This cyst contained progesterone, with no detectable amounts of any other steroid. $\times 200$.

Fig. 7. Cystic ovary. Cow 22. This is a true luteal cyst. There are typical luteal cells present, interspersed with stromal connective tissue. A broad band of fibrous connective tissue separates the luteal tissue from the lumen of the cyst. The cyst fluid contained relatively large amounts of progesterone and $20 \beta$-hydroxypregn-4-en-3-one and a trace of oestradiol-17 $\beta . \times 200$. 